ISSN 2078-6441. Вісник Львівського університету. Серія географічна. 2014. Випуск 47. С. 202-208. Visnyk of the Lviv University. Series Geography. 2014. Issue 47. P. 202-208.

$338.488(477.85)$

\author{
рія Л м рюк \\ ернівецький н ціон льний університет імені рія едькович , \\ вул. оцюбинського, 2, 58012, м. ернівці, кр їн
}

ро н лізов но просторове розміщення с н торно-курортних з кл дів у розрізі дміністр тивних $\mathrm{p}$ йонів ернівецької обл. иділено $\mathrm{p}$ йони зі зн чною т недост тньою з безпеченістю с н торно-курортними 3 кл д ми. бгрунтов но передумови і причини розміщення с н торнокурортних 3 кл дів. ро н лізов но пок зники діяльності с н торно-курортних 3 кл дів ернівецької обл. озглянуто проблеми т перспективи розвитку с н торно-курортної спр ви.

лючові слов : с н торно-курортн спр в , природні лікув льні ресурси, курорт, с н торнокурортні з кл ди, с н торій, п нсіон т.

днією з н йст більніших ринкових структур є ринок пропозиції курортних послуг, що зумовлено як необхідністю лікув ння, т к і пр ктикою з побіг ння хвороб м, що ст новить скл дову життєвого ст нд рту у високоіндустрі льних кр їн х і поширюється н щор з ширші кол н селення інших кр ї [7]. н торно-курортне господ рство перев жно створюють у місцях зосередження сприятливих рекре ційних ресурсів, лікув льні т оздоровчі вл стивості яких м ють територі льні особливості. е визн ч $е$ спеці ліз цію с н торно-курортних регіонів н н д нні певних видів лікув льних чи відпочинкових послуг. ому з безпечення н лежними с н торно-курортними з кл д ми перетворюється в н г льну проблему сьогодення.

йбільшу прив бливість серед курортних територій кр їи м ють рим, к рп тськ т в но- р нківськ, деськ, рківськ, ернівецьк, ьвівськ т иївськ обл сті [1]. снують тр диційні і перспективні с н торно-курортні $\mathrm{p}$ йони з унік льними природними ресурс ми для відпочинку і лікув ння. дним із критеріїв перспективного с н торно-курортного будівництв $є$ н явність бо відсутність у певній місцевості гідромінер льних ресурсів. н ліз діяльності с н торно-курортних з кл дів ернівецької обл. є основним з вд нням н шого дослідження.

оч в ернівецькій обл. офіційного ст тусу курорту не м є жоден н селений пункт, тут функціонують чотири с н торії (без ур хув ння протитуберкульозних), один с н торій-профіл кторій, дв п нсіон ти з лікув нням, чотири б зи відпочинку.

н торно-курортні т оздоровчі 3 кл ди н території ернівецької обл. розміщені нерівномірно: м йже всі вони є у торожинецькому, овоселицькому, ижницькому,

ст внівському т іцм нському р йон х (див. т бл. 1). йбільше їх н торожинеччині: серед н явних т м оздоровчих з кл дів дв с н торії (у тім числі один дитячий) $\mathrm{i}$ одн 6 з відпочинку. овсім нем є оздоровчих з кл дів у утильському р-ні, хоч природні ресурси для розвитку рекре ційного господ рств т м $€$. гірському утильському р-ні з різними клім тичними умов ми - від помірного клім ту н півночі до холодного в південній ч стині - є висхідні джерел хлоридних н трієвих вод,

(C) л м рюк ., 2014 
хлоридної к льцієво-н трієвої води м лої мінер ліз ції, сл бкомінер лізов ної хлоридно-гідрок рбон тної н трієвої з домішк ми орг нічних сполук, м ломінер лізов ної гідрок рбон тної м гнієво-к льцієвої з орг нічними сполук ми, сірководневої гідрок рбон тної н трієво-к льцевої т ін. і води використовує місцеве н селення.

ем є т кож ще лікув льного з стосув ння хлоридно-н трієвої води типу иргородськ , як виявлен в с. жі окирянського р-ну. ільшість мінер льних вод досі н лежно не з стосовують. ут потенційні можливості для розвитку с н торної спр ви зн чною мірою не використ ні.

н торно-курортні (оздоровчі) з кл ди ернівецької обл.

\begin{tabular}{|c|c|c|c|}
\hline $\begin{array}{l}\text { 3в С н торно-оздоровчого } \\
\text { з кл ду }\end{array}$ & озт шув ння & $\begin{array}{r}\text { іль- } \\
\text { кість } \\
\text { місць } \\
\end{array}$ & пеці ліз ція з кл ду \\
\hline \multicolumn{4}{|c|}{ н торії } \\
\hline $\begin{array}{l}\text { н торій-профіл кторій } \\
\text { ернівецького університету }\end{array}$ & м. ернівці & 50 & г льнотер певтичний \\
\hline $\begin{array}{l}\text { русницьк обл сн б льнео- } \\
\text { логічн лік рня відновного } \\
\text { лікув ння }\end{array}$ & $\begin{array}{l}\text { іцм нський p-н, } \\
\text { с. русниця }\end{array}$ & 150 & $\begin{array}{l}\text { хворюв ння опорно- } \\
\text { рухового п р ту, серцево- } \\
\text { судинної, нервової системи, } \\
\text { шлунково-кишкового } \\
\text { тр кту, гінекологічні т } \\
\text { шкірні недуги }\end{array}$ \\
\hline итячий с н торій “ ербинці” & $\begin{array}{l}\text { овоселицький р-н, } \\
\text { с. ербинці }\end{array}$ & 60 & $\begin{array}{l}\text { хворюв ння опорно- } \\
\text { рухового п р ту, } \\
\text { остеохондроз, ревм тизм } \\
\end{array}$ \\
\hline н торій “ олотий колос” & $\begin{array}{l}\text { торожинецький p-н, } \\
\text { с. } \quad \text { нк }\end{array}$ & 185 & $\begin{array}{l}\text { олі ртрит, гіпертонія, } \\
\text { псорі 3, р дикуліт, серцево- } \\
\text { судинн систем , з хворю- } \\
\text { в ння шкіри, нервов } \\
\text { систем }\end{array}$ \\
\hline $\begin{array}{l}\text { итячий г строентерологічний } \\
\text { с н торій “ т p дов ” }\end{array}$ & $\begin{array}{l}\text { торожинецький p-н, } \\
\text { с. т р дов }\end{array}$ & 100 & $\begin{array}{l}\text { лунково-кишковий тр кт, } \\
\text { г строентерологія }\end{array}$ \\
\hline \multicolumn{4}{|c|}{ нсіон ти } \\
\hline $\begin{array}{l}\text { нсіон т з лікув нням } \\
\text { “ елені п горби” }\end{array}$ & $\begin{array}{l}\text { ижницький p-н } \\
\text { с. иженк }\end{array}$ & 220 & г льнотер певтичний \\
\hline $\begin{array}{l}\text { нсіон т з лікув нням } \\
\text { еремош” }\end{array}$ & $\begin{array}{l}\text { ижницький } \mathrm{p}-\mathrm{H} \\
\text { м. ижниця } \\
\end{array}$ & 320 & г льнотер певтичний \\
\hline \multicolumn{4}{|c|}{ зи відпочинку } \\
\hline $\begin{array}{l}3 \text { відпочинку } \\
\text { “ уковинський г й” }\end{array}$ & $\begin{array}{l}\text { ст внівський p-н } \\
\text { с. епужинці }\end{array}$ & 62 & $\begin{array}{r}\text { ідпочинок для всіх } \\
\text { К тегорій н селення }\end{array}$ \\
\hline з відпочинку “ доров’я” & $\begin{array}{l}\text { ст внівський р-н } \\
\text { с. епужинці }\end{array}$ & 100 & $\begin{array}{r}\text { ідпочинок для всіх } \\
\text { К тегорій н селення } \\
\end{array}$ \\
\hline з відпочинку “ орнівк ” & $\begin{array}{l}\text { овоселицький р-н, } \\
\text { с. орнівк }\end{array}$ & 146 & $\begin{array}{r}\text { ідпочинок для всіх } \\
\text { К тегорій н селення }\end{array}$ \\
\hline з відпочинку “ ин мо” & $\begin{array}{l}\text { торожинецький р-н } \\
\text { c. } \quad \text { м'ян }\end{array}$ & 25 & $\begin{array}{r}\text { ідпочинок для всіх } \\
\text { К тегорій н селення } \\
\end{array}$ \\
\hline
\end{tabular}


оротко сх р ктеризуємо курортно-рекре ційний фонд ернівецької обл.

н торії $m$ n нсіон ти з лікув нням. ьогодні н території ернівецької обл. функціонують п'ять с н торіїв т дв п нсіон ти з лікув нням, ліжковий фонд яких ст новить 667 ліжок. них оздоровлено 2068 хворих (т бл. 2). ри з цих с н торіїв розміщені в торожинецькому р-ні. они м ють різну лікув льну спеці ліз цію: г строендереологічну (для дітей), туберкульозну (для дорослих), серцево-судинну,

т кож є профіль лікув ння опорно-рухового п р ту (для дорослих) т нервової системи.

блиця 2

сновні пок зники діяльності с н торно-курортних (оздоровчих) з кл дів [3]

\begin{tabular}{|c|c|c|c|c|c|c|}
\hline \multirow{3}{*}{ ок Зник } & \multirow{3}{*}{$\begin{array}{l}\text { ількість } \\
3 \text { кл дів }\end{array}$} & \multicolumn{2}{|c|}{$\begin{array}{l}\text { них ліжок } \\
\text { (місць) }\end{array}$} & \multirow{2}{*}{\multicolumn{2}{|c|}{$\begin{array}{c}\text { ількість осіб, що } \\
\text { були оздоровлені } \\
\text { протягом }\end{array}$}} & \multirow{3}{*}{$\begin{array}{c}\text { ількість } \\
\text { фктично } \\
\text { проведених } \\
\text { ліжко-днів } \\
\text { (людино-днів) } \\
\text { усім оздоров- } \\
\text { леними }\end{array}$} \\
\hline & & \multirow[b]{2}{*}{$\begin{array}{l}\text { цілоріч- } \\
\text { них }\end{array}$} & \multirow{2}{*}{$\begin{array}{c}\text { у місяць } \\
\text { м кси- } \\
\text { м льно- } \\
\text { го роз- } \\
\text { горт ння }\end{array}$} & & & \\
\hline & & & & $\begin{array}{c}\text { трив лого } \\
\text { ч су }\end{array}$ & 1-2 днів & \\
\hline сього 3 кл дів & 11 & 717 & 1282 & 1503 & 1028 & 86239 \\
\hline \multicolumn{7}{|l|}{ у тому числі } \\
\hline с н торії & 5 & 617 & 677 & 1165 & - & 81371 \\
\hline 3 них дитячі & 3 & 370 & 430 & 986 & - & 72636 \\
\hline $\begin{array}{l}\text { с н торії для хворих н } \\
\text { туберкульоз }\end{array}$ & 2 & 332 & 332 & 1165 & - & 81371 \\
\hline 3 них дитячих & 1 & 270 & 270 & 986 & - & 72636 \\
\hline П нсіон ти з лікув нням & 1 & 50 & 220 & 129 & 774 & 3033 \\
\hline с н торії-профіл кторії & 1 & 50 & 50 & - & - & - \\
\hline $\begin{array}{l}6 \text { зи т інші з кл ди } \\
\text { відпочинку }\end{array}$ & 4 & - & 335 & 209 & 254 & 1835 \\
\hline
\end{tabular}

кож у овоселицькому р-ні розт шов ний с н торій к рдіологічного профілю для дітей, в ернівцях (теж дитячий) функціонує облтубс н торій. усього ліжкового фонду всіх с н торіїв близько половини ліжок існує для лікув ння туберкульозу легень.

нсіон т з лікув нням м тері і дитини “елені п горби” розмістився н території н ціон льного природного п рку “ ижницький” у б сейні високогірних річок еремош т ірет у с. иженк ижницького р-ну ернівецької обл. ериторія п нсіон ту охоплює 5,3 г і є н лівому березі р. иженк . ідст нь від п нсіон ту до м. ижниця - 5 км, до м. ернівці - 80 км.

нсіон т як оздоровчо-лікув льний з кл д функціонує з 1996 р. н 6 зі колишнього будинку відпочинку “ елені п горби” і перебув є н б л нсі ернівецької облпрофp ди. ротягом б г тьох років сюди приїждж ють десятки тисяч людей, щоб відпочити і поліпшити своє здоров'я. ля культурно-м сового відпочинку є будинок дозвілля, бібліотек, спортивний т дитячий м йд нчики.

2007 р. у р йоні п нсіон ту обл дн но п’ять туристичних м ршрутів. ині трив $\epsilon$ добудов сп льного корпусу з усім зручностями н 84 місця.

русницьк обл сн лік рня відновного лікув ння з снов н 1968 р. он розміщен в м льовничому п рку н околиці с. русниця, де колись стояв м єток фр нцузького 
гр ф де- ск ло. 1980 р. тут збудов но сп льний корпус н 150 місць. одолік рня функціонує н родовищ $\mathrm{x}$ сірководневої води високої концентр ції, 3 хімічним скл дом подібної н м цестинську ( очі); гідрок рбон тно-хлоридно-н трієвої води типу сентуки, т хлоридно-н трієвої води, що $є$ н логом иргородської. ині пр цюють три робочі свердловини, дв дцять 3 консервов ні. Г лом родовищ мінер льних вод зд тні д в ти $150 \mathrm{~m}^{3}$ води 3 добу, що д є змогу щоденно лікув ти 2 тис. п цієнтів.

ьогодні тут лікують 3 хворюв ння опорно-рухового п р ту, серцево-судинної, нервової системи, шлунково-кишкового тр кту, гінекологічні т шкірні недуги. русниці з стосовують унік льну методику підводного витягув ння хребт . исоку ефективність м є лікув ння з допомогою озокериту, який з возять 3 рогобич у спеці льних ч н х, розігрів ють до певної темпер тури і використовують у вигляді плік цій.

о недоліків оздоровчого з кл ду н леж ть побутові умови: сп льний корпус русницької водолік рні вже д вно потребує к піт льного ремонту.

нсіон т з лікув нням “ еремош” розт шов ний н околиці ижниці у івні. ін створений 1975 р. як обл сне дочірнє підприємство “ ернівцітурист”. нсіон т функціонує цілорічно, розр хов ний н 320 місць у літні період і 120 в осінньозимовий. ут є шість будиночків зі всім зручностями: ту лет, г ряч вод, душ; кімн ти дво-, чотири- і шестимісні; т кож чотири літні будиночки і десять чотиримісних будиночків. території п нсіон ту є їд льня з двом з л ми н 120 місць, у р зі потреби з дієтичним х рчув нням, будинок дозвілля, бібліотек , спортивний і дитячий м йд нчики, с ун .

літку п нсіон т функціонує як дитячий оздоровчий т бір, де цілющі вл стивості гірського клім ту поєднують із куп нням у р. еремош і різном нітними пішохідними м ршрут ми по уковинських рп т х.

езв ж ючи н н явність лікув льних ресурсів, в обл сті нем $є$ с н торіїв, які 6 спеці лізув лись н лікув нні урологічних, гінекологічних, дерм тологічних 3 хворюв нь. ем $€$ т кож с н торіїв для лікув ння орг нів тр влення т обміну речовин, орг нів дих ння нетуберкульозного х р ктеру для дорослих.

оцільно провести гідрогеологічні дослідження з визн чення з п сів мінер льних вод у ербинцях, иженці, ерешенці. к ув ж ютьф хівці, у с. ерешеньк можливе будівництво с н торію н 500 місць для лікув ння орг нів тр влення, опорно-рухового п р ту, гінекологічних т дерм тологічних 3 хворюв нь, у иженці - с н торію н 500 ліжок для лікув ння орг нів тр влення т обміну речовин, т кож урологічних 3 хворюв нь.

евне господ рське зн чення м є розлив лікув льних вод, який збільшує можливості використ ння їх з метою лікув ння. ьогодні в ернівецькій обл. ведуть розлив т ких вод, як ельменецьк, еленч нськ, русницьк т жевськ .

н торії-профіл кторії. відміну від інших с н торно-курортних 3 кл дів, с н торії-профіл кторії призн чені для дод ткового лікув ння $\mathrm{T}$ оздоровлення пр цівників без відриву від трудової діяльності у вільний від роботи ч с упродовж 24 днів. хня орг ніз ція сприяє зн чному зниженню з хворюв нь. ині в ернівецькій обл. $з$ д ними обл сного ст тистичного упр вління функціонує один т кий з кл д н 50 місць.

удинки відпочинку. оловною причиною сл бкого розвитку будинків відпочинку $\epsilon$ деяк невідповідність цього типу з кл дів новим тенденціям у змін х с мої структури рекре ції, т кож у соці льно-економічному житті н шого суспільств · оцільно було 
6 розвив ти спеці лізов ні будинки відпочинку для молоді, людей похилого віку, головне - сімейних. е д ло б змогу більше з безпечити норм тивну потребу ліжковим фондом.

зи відпочинку. Зи відпочинку, їх усього чотири, розміщені в ст внівському (дві), овоселицькому (одн ) т торожинецькому (одн ) р йон х (див. т бл. 1). хній $з$ г льний ліжковий фонд ст новить 335 ліжок, кількість відпочив льників 463 осіб (див. т бл. 2).

ля хворих н туберкульоз н території обл сті діяло дв с н торії н 332 ліжк , з них один - для дітей н 270 ліжок.

с н торно-курортних (оздоровчих) з кл д х 2011 р. відновлюв ли здоров’я 1503 особи, що н 4,2\% більше, ніж 2010 р. еред оздоровлених 59,3\% ст новили діти. уло оздоровлено 52 постр жд лих ун слідок в рії н . рім того, протягом одного-двох днів у оздоровчих з кл д х відпочило 1028 осіб, що н 18,4\% більше, ніж 2010 р. (див. т бл. 2).

іяльність с н торно-курортних (оздоровчих) з кл дів з безпечув ли 352 пр цівники, $з$ них 21 лік р, 78 пр цівників середнього медичного персон лу т 253 інші пр цівники. с н торіях пр цюв ло 312 осіб (з них у дитячих - 231 особ ), у п нсіон т х $з$ лікув нням - 25, н йменше пр цівників було н 6 з х відпочинку (15 осіб).

$6 з$ х відпочинку передб чене обслуговув ння терміном перебув ння як три і більше днів, т к і один-дв дні; вони призн чені для щорічного т щонедільного короткоч сного відпочинку. е н йбільш м сов т дин мічн форм відпочинку. ї ктивне формув ння простежується ост ннім десятиліттям, що пояснюють не тільки популярністю сімейного відпочинку, й потребою в розвитку короткотермінового відпочинку.

ернівецькій обл. 2011 р. протягом трив лого ч су оздоровлюв лися 1503 особи, перев жно у с н торіях (1 165 осіб), $\quad$ т кож і в П нсіон т х (129 осіб).

ротягом одного-двох днів 2011 р. відпочив ло 1028 осіб, з них 774 особи у п нсіон ті з лікув нням “елені п горби”, що у ижницькому р-ні т 254 особи н $б$ зі відпочинку у ст внівському р-ні.

ля зміцнення здоров'я дітей в жливе зн чення м є орг нізов ний відпочинок під ч с літніх к нікул. дним 3 н йбільш м сових т доступних видів орг нізов ного відпочинку школярів є проведення літніх к нікул в оздоровчих т бор х.

міські т бори відпочинку дітей - це вихов льно-оздоровчі 3 кл ди для дітей 7-17 років, вони розміщені ч стково у вл сних приміщеннях, деякі з них - у орендов них. ернівецькій обл. протягом трив лого ч су були оздоровлені 1109 дітей, відпочив ли протягом одного-двох днів 204 особи. літку 2011 р. н території обл сті діяло 402 дитячі оздоровчі т бори н 3,7 тис. місць, з яких 382 - пристосов ні (з денним перебув нням), 15 - ст ціон рні (12 поз міських оздоровчих т 3 с н торного типу), 5 - н метові (4 профільні т 1 інший). 17,2 тис. - 3 м лоз безпечених, б г тодітних т неповних сімей, 1,6 тис. - постр жд лі вн слідок в рії н , м йже 1 тис. - сироти т позб влені 6 тьківського піклув ння, 0,8 тис. - інв ліди.

орівняно з 2010 р. кількість дитячих оздоровчих з кл дів зменшил сь н один т бір, кількість дітей, які відпочив ли в цих т бор х, - н 2,1\%, кількість місць у т бор х зменшил сь н 10,8\%. ількість оздоровчих т борів у розрізі дміністр тивних р йонів 2011 р. не змінил ся, якщо порівнюв ти з 2010 р. (з винятком іцм нського р-ну). 
йбільше т борів зосереджено в торожинецькому р йоні $(13,2 \%$ від з г льної кількості), т кож либоцькому $(10,1)$, овоселицькому $(9,2)$, м. ернівці $(8,9)$, іцм нському $(8,7)$, ст внівському $(8,7)$, отинському $(8,4)$, ижницькому $(8,4)$. йменше т борів зосереджено в утильському р-ні $(4,4 \%)$ т м. оводністровськ $(1,2 \%)$.

2011 р. кількість оздоровлених дітей зменшил ся н 1179 осіб (порівняно з 2010 р.). е пов'яз но зі зменшенням кількості дитячих т борів. йбільше дітей відпочив ло в оздоровчих т бор х торожинецького р-ну (18,5\% від з г льної кількості).

кщо простежити дин міку кількості дітей, оздоровлених улітку з період 20052010 pр., то н йвищі пок зники були у 2007 р. (48,4 тис. осіб) у пристосов них т бор х. ількість дітей, оздоровлених у ст ціон рних т бор х, поступово зменшув л сь з 13,2 тис. осіб у 2005 р. до 8,5 тис. осіб у 2009 р. е пов'яз но зі зменшенням кількості ст ціон рних т борів. 2009 р. н $40 \%$ зросл кількість дітей, оздоровлених у н метових т бор х (порівняно з 2008 р.).

тже, тенденції, що н мітилися в с н торно-курортній сфері ернівецької обл., свідч ть про зменшення кількості с н торно-курортних з кл дів. сновними причин ми т ких змін було перепрофілюв ння низки п нсіон тів з лікув нням у с н торії т 3 криття нерент бельних с н торіїв-профіл кторіїв (здебільшого тих, які перебув ли н б л нс х окремих підприємств). еякі оздоровчі з кл ди є уз недб ному ст ні т не діють.

езв ж ючи н н явність лікув льних ресурсів, в обл сті нем $є$ с н торіїв, які б спеці лізув лись н лікув нні урологічних, гінекологічних, дерм тологічних 3 хворюв нь. ем є т кож с н торіїв для лікув ння орг нів тр влення т обміну речовин, орг нів дих ння нетуберкульозного х р ктеру для дорослих. процесі реформув ння с н торно-курортної г лузі досягнення н уки вб ч ють рушійною силою, що з безпечує всебічне обгрунтув ння необхідності перебудови г лузі, визн чення прогнозних потреб н селення у с н торно-курортному лікув нні, медичній ре біліт ції т оздоровленні, т кож розроблення з ходів щодо їхнього поліпшення.

1. урортні ресурси кр їни / [3 ред. проф. . . . ободи]. - . . крпрофоздоровниця, “ мед”, 1999. - 334 с.

2. усков . . урортология и оздоровительный туризм : учеб. пособие / . . усков, . . ысиков .- остов-н - ону : еникс, 2004. - 320 с.

3. т тистичний збірник. уризм, відпочинок т с н торно-курортне лікув ння в обл сті. - ернівці : оловне упр вління ст тистики в ернівецькій обл сті. - 2012. - 65 с.

4. $\kappa$ ченко . ро поняття курортно-оздоровчих т рекре ційних зон в екологічному 3 конод встві / . к ченко // існик к демії пр вових н ук кр їни. - 1998. №1 (12). - . 139-142.

5. опчиев . . еоэкология: геогр фические основы природопользов ния / . . опчиев. - десс : стропринт, 1996. - 392 с.

6. опчієв . . успільно-геогр фічне дослідження: методологія, методи, методики : н вч. посібник / . . опчієв. - дес : стропринт, 2005. - 632 с.

7. оменко . . екре ційні ресурси т курортологія: н вч. посібник / . . оменко. - . : ентр н вч льної літер тури, 2007. - 312 с.

m ття: н дійшл до ред кції 22.09.2014

доопр иьов н 15.10 .2014

прийнят до друку 19.11.2014 


\section{ANALYSIS OF HEALTH RESORT INSTITUTIONS IN CHERNIVTSI REGION}

\section{Mariya Palamaryuk}

Yuriy Fedkovych Chernivtsi National University, Kotsyubynskyj Str., 2, UA - 58012 Chernivtsi, Ukraine

Spatial location of spa facilities in the context of administrative districts of Chernivtsi region was analyzed. Areas with significant and insufficient provision of sanatorium and resort facilities were highlighted. Background and reasons of placement of spa facilities were justified. Performance of spa facilities in Chernivtsi region was analyzed. Problems and prospects of development of sanatorium cases were considered.

Key words: health-resort business, natural medical resources, resort, spa facilities, holiday house. 